\author{
Wiesław KUBISZYN ${ }^{1}$
}

\title{
KSZTALTOWANIE, PROJEKTOWANIE I WYKONAWSTWO STALOWYCH PRZEWODÓW SPALINOWYCH KOMINÓW DWUPOWŁOKOWYCH
}

\begin{abstract}
$\mathrm{W}$ artykule przedstawiono zagadnienia związane z kształtowaniem, projektowaniem i wykonawstwem przewodów spalinowych ze stali odpornej na korozję w kominach stalowych dwupowłokowych. Na przykładzie zrealizowanego komina dwupowłokowego omówiono problemy zapewnienia odpowiedniej trwałości w projektowaniu przewodów spalinowych $\mathrm{z}$ uwzględnieniem wymagań PN-EN 1993-3-2 oraz PN-EN 13084-1. Opisano przyjęte rozwiązania materiałowokonstrukcyjne oraz zasady wykonawstwa tych przewodów spalinowych - wkładów kominowych. Przedstawiono również zasady projektowania wkładów kominowych $\mathrm{z}$ uwzględnieniem oddziaływania różnicy temperatury według PN-EN 13084-6. Te zasady projektowe zostały zilustrowane odpowiednim przykładem obliczeniowym. W podsumowaniu artykułu zarekomendowano realizację stalowych kominów dwupowłokowych z wkładem ze stali nierdzewnej jako rozwiązań spełniających aktualne wymagania normowe związane z projektowaniem budowli na założoną trwałość.
\end{abstract}

Słowa kluczowe: kominy stalowe, stal nierdzewna, wykładziny stalowe, trwałość kominów stalowych, oddziaływanie różnicy temperatury

\section{Wprowadzenie}

Kominy stalowe zalicza się do budowli wysokich o specjalnym przeznaczeniu, których głównym zadaniem jest odprowadzenie spalin lub gazów w wyższe warstwy atmosfery. Kominy te można przede wszystkim podzielić na spalinowe, wentylacyjne i specjalne. Najliczniejszą grupę stanowią kominy spalinowe, które odprowadzają do atmosfery spaliny powstające w procesie spalania paliwa - węgla, gazu lub oleju opałowego. Jedną ze szczególnych cech tych specjalnych budowli przemysłowych jest ich stosunkowo niska trwałość (krótki okres eksploatacji) wynikająca z podatność stali trzonu nośnego na korozję zewnętrzną a przede wszystkim wewnętrzną, związaną z eksploatacją w bardzo trudnych warunkach. Dodatkowymi czynnikami obniżającymi trwa-

\footnotetext{
${ }^{1}$ Autor do korespondencji:Politechnika Rzeszowska Katedra Konstrukcji Budowlanych, ul. Po-
} znańska 2, 35-084 Rzeszów, tel. +48 17865 16 28, e-mail: wkubisz@.prz.edu.pl, 
łość kominów stalowych jest działanie wysokiej temperatury i podatność na drgania wywołane dynamicznym oddziaływaniem wiatru. Wszystkie te negatywnie oddziaływujące czynniki muszą być uwzględniane $\mathrm{w}$ procedurach projektowania tych konstrukcji. Poprawne przyjęcie rozwiązań technologicznych i materiałowo - konstrukcyjnych, odpowiednia kultura wykonawstwa $\mathrm{z}$ zachowaniem reżimów technologicznych oraz eksploatacja $\mathrm{w}$ warunkach zgodnych z założeniami projektowymi gwarantują odpowiedni okres eksploatacji kominów stalowych, bez wyraźnego obniżenia walorów użytkowych i bez potrzeby generalnych remontów.

$\mathrm{W}$ artykule przedstawiono wybrane zagadnienia związane $\mathrm{z}$ kształtowaniem, projektowaniem i wykonawstwem przewodów spalinowych ze stali stopowej odpornej na korozję stosowanych między innymi w kominach dwupowłokowych. Na przykładzie zrealizowanego komina dwupowłokowego zostaną omówione następujące zagadnienia:

- zapewnienia odpowiedniej trwałości w projektowaniu przewodów spalinowych kominów dwupowłokowych z uwzględnieniem wymagań najnowszych standardów według PN-EN 1993-3-2 [3] i norm związanych,

- poprawnego kształtowania oraz wykonawstwa przewodów spalinowych ze stali nierdzewnej,

- zasad projektowania stalowych wkładów kominowych pod wpływem oddziaływania różnicy temperatury.

\section{Trwałość kominów stalowych}

Normy europejskie związane z projektowaniem konstrukcji budowlanych zwracają większą uwagę, niż dotychczasowe normy polskie, na zagadnienia zapewnienia odpowiedniej trwałości. Zagadnienia dotyczące trwałości kominów stalowych zostały opisane w pracy [8], gdzie szczegółowo omówiono:

- $\quad$ wpływ przyjętych rozwiązań konstrukcyjnych i materiałowych oraz zabezpieczeń antykorozyjnych na odporność korozyjną projektowanych kominów stalowych,

- $\quad$ zasady kształtowania połączeń stali nierdzewnej (stopowej odpornej na korozję) i zwykłej węglowej (niestopowej).

Wprowadzenie wymogów Eurokodów do projektowania kominów stalowych spowodowało konieczność stosowania stali nierdzewnej [8], a biorąc pod uwagę rachunek ekonomiczny celowym rozwiązaniem staje się realizacja kominów dwupowłokowych, w których wyraźnie są rozdzielone funkcje technologiczna i nośna - konstrukcyjna. Komin dwupowłokowy [3] posiada zewnętrzny trzon nośny ze stali zwykłej niestopowej, przenosi on wszystkie oddziaływania zewnętrzne oraz wkład spalinowy - przewód wewnętrzny z odpowiednio dobranej, adekwatnie do obciążenia korozyjnego, stali najkorzystniej nierdzewnej. Przykładowe rozwiązania konstrukcyjne komina dwupowłokowe- 
go pokazano na rysunkach 1. i 3. Wykonawstwo segmentów przewodów spalinowych ze stali nierdzewnej wymaga zachowania szczególnych reżimów technologicznych podanych m.in. w normie PN-EN 1993-1-4 [1].
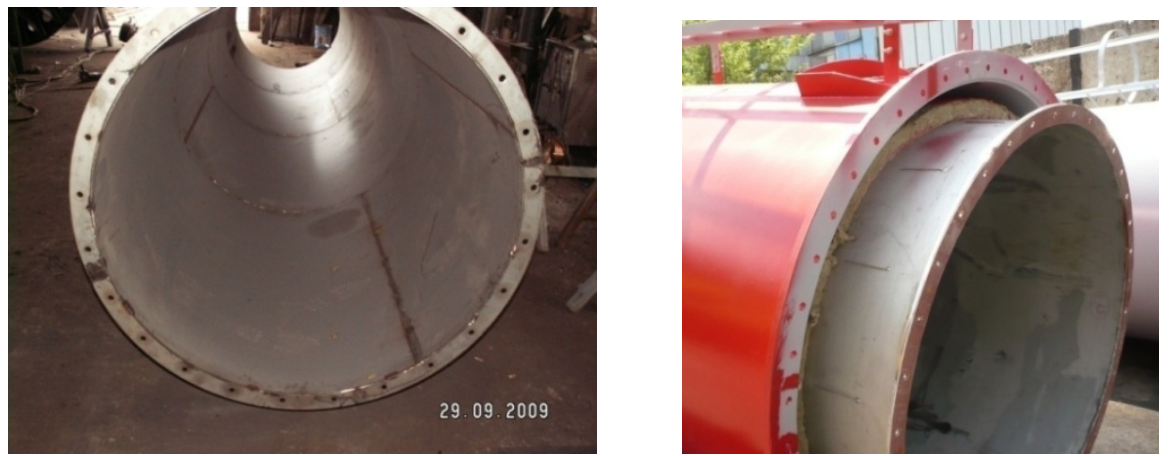

Rys. 1. Widok segmentu przewodu spalinowego trakcie wykonawstwa i podczas montażu

Fig. 1. View of segment of the flue pipe (liner) during execution and assembly

Zachowanie tych wymagań pozwala na uzyskanie (utrzymanie) optymalnej odporności korozyjnej stali nierdzewnej. Przy wykonywaniu przewodu spalinowego należy unikać przenoszenia cząstek stali węglowej zwykłej na stal nierdzewną. Najlepiej poprzez wydzielenie specjalnych pomieszczeń i narzędzi przeznaczonych do obróbki tylko stali nierdzewnej. Szczególne ma to znaczenie w procesie walcowania blach na przewód oraz ich mechanicznego cięcia. Poniżej przedstawiono kilka zasad, którymi należy się kierować podczas wykonywania połączeń spawanych, po wykonywaniu tych połączeń należy:

- usunąć rozpryski stopiwa,

- lico spoin zeszlifować i oczyścić szczotkami ze stali nierdzewnej a następnie wytrawić za pomocą odpowiednich preparatów (żelów, past lub kąpieli),

- po wytrawianiu, powierzchnię elementów zmyć obficie wodą, wskazane jest stosowanie wody zdemineralizowanej (destylowanej) do końcowego płukania,

- wykonać pasywację miejsc spawania i ewentualnych uszkodzeń mechanicznych,

- przebarwienia (barwy nalotowe) pochodzące od spawania, widoczne na powierzchni stali nierdzewnych, obniżające ich odporność na korozję należy usunąć poprzez wytrawienie a następnie wykonać pasywację wytrawionych powierzchni.

Wymienione zabiegi nie tylko poprawiają wygląd spawanych elementów konstrukcji, ale przede wszystkim w pełni przywracają odporność stali nierdzewnej na korozję. Brak realizacji powyższych zaleceń, szczególnie w rejonach połączeń spawanych i uszkodzeń mechanicznych powierzchni blach 
ze stali nierdzewnej prowadzi w stosunkowo krótkim czasie (kilku lat) do zniszczeń korozyjnych przedstawionych w artykule [8].

Innym ważnym zagadnieniem związanym $\mathrm{z}$ projektowaniem przewodów spalinowych ze stali nierdzewnej jest prawidłowe ukształtowanie i wykonawstwo styków segmentów. Taki przykładowy styk pokazano na rys. 3 . - szczegół B. Istotny tutaj jest właściwy dobór rodzaju śrub - gatunku stali dostosowanej do gatunku stali stosowanej na przewód kominowy i ich klasy oraz prawidłowe ukształtowanie $\mathrm{i}$ wykonanie, $\mathrm{z}$ użyciem kompatybilnych materiałów spawalniczych, połączeń spawanych. Dotyczy to zarówno spoin łączących kołnierz ze ścianką przewodu spalinowego, jak i połączeń na spoiny czołowe blach pomiędzy sobą.

\section{Oddziaływanie różnicy temperatury ścianki wykładziny}

Jednym z czynników obniżającym trwałość kominów stalowych jest działanie wysokiej temperatury spalin, odprowadzane spaliny mogą również powodować nierównomierne nagrzewanie przewodu (wkładu) kominowego. Największa różnica temperatury ścianki przewodu spalinowego powstaje przy wlocie czopucha (kanału spalin) do przewodu spalinowego. Różnica temperatury na przeciwległych ściankach przewodu spalinowego, bądź wykładziny kominowej (rys. 2.) powoduje powstanie różnych wielkości odkształceń - wydłużeń skutkujących powstaniem momentów zginających, które należy uwzględniać przy projektowaniu tych stalowych przewodów spalinowych. Określenie wielkości różnicy temperatury oddziaływującej na przewód spalinowy (rys 2.) dokonuje się według normy PN-EN 13084 - 6 [5], przyjmując do dalszych obliczeń wartość mniejszą z dwóch wzorów numer (1) lub (2).

$$
\begin{aligned}
& \Delta \mathrm{T}=0,1 \mathrm{~T}_{\max }, \text { lecz nie mniej niż } \Delta \mathrm{T}_{\min }=15 \mathrm{~K} ; \\
& \Delta \mathrm{T}=\Delta \mathrm{T}^{\prime} \frac{\pi}{2} \mathrm{D} ;
\end{aligned}
$$

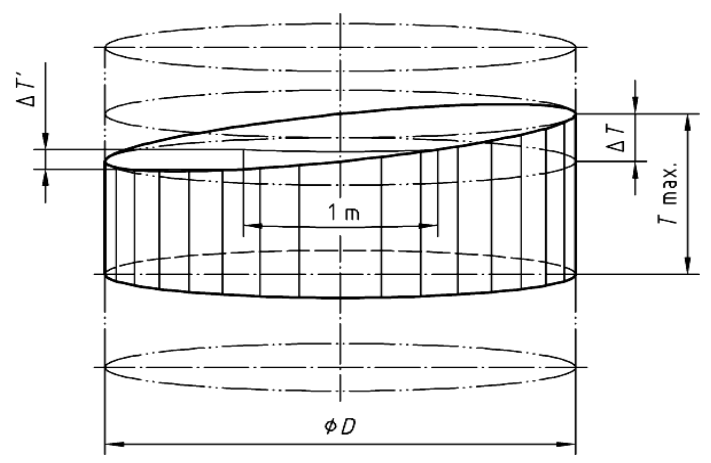

Rys. 2. Liniowa różnica temperatur według PN-EN 13084-6 [5]

Fig. 2. Linear temperature difference by PN-EN 13084-6 [5] 


$$
\Delta T^{\prime}=4 \frac{T_{\max }}{150}, \text { lecz nie mniej niż } \Delta \mathrm{T}^{\prime}=\mathrm{K} / \mathrm{m},
$$

gdzie: $\mathrm{T}_{\max }$ jest maksymalną obliczeniowa temperaturą spalin wyrażoną $\mathrm{w}\left[{ }^{\circ} \mathrm{C}\right]$;

$\mathrm{D}$ jest średnicą przewodu spalinowego określaną $\mathrm{w}[\mathrm{m}]$

$\Delta \mathrm{T}^{\prime}$ jest obwodowym gradientem temperatury podstawianym do wzoru $\mathrm{w}[\mathrm{K} / \mathrm{m}]$.

\section{Przykład wymiarowania przewodu spalinowego}

\section{Założenia projektowe}

Średnica zewnętrzna przewodu spalinowego $\mathrm{d}_{\mathrm{z}}=1620 \mathrm{~mm}$;

Stal nierdzewna gatunku 1.4404

Maksymalna temperatura spalin $\mathrm{T}_{\max }=200^{\circ} \mathrm{C}$

Parametry wytrzymałościowe stali przewodu przy maksymalnej temperaturze spalin [5]: $\mathrm{f}_{\mathrm{y}}=137 \mathrm{MPa} ; \mathrm{E}_{\mathrm{c}}=190 \mathrm{MPa}$;

współczynniki częściowe materiałowe według [1] $\gamma_{M_{0}}=1,10 ; \gamma_{M_{1}}=1,10$.

Współczynnik rozszerzalności liniowej $\alpha_{\mathrm{T}}=16,5 \times 10^{-5}$; Intensywność korozji $0,25 \mathrm{~mm} / 10$ lat przy średnim (M) stopniu działania korozyjnego [4]; czas eksploatacji komina 30 lat. Potrzebny naddatek korozyjny wewnętrzny $C_{\text {int }}=0,25$ x 30/10 = 0,75 mm. Przyjęta wyjściowa nominalna grubość ścianki przewodu spalinowego (rys. 3.) $t_{\text {nom }}=4 \mathrm{~mm}$. Obliczeniowa grubość przewodu spalinowego $\mathrm{t}=4-0,75=3,25 \mathrm{~mm}$.

Parametr jakości wytwarzania: jakość normalna $\mathrm{C}-Q_{x}=\mathbf{1 6}$.

Współczynniki częściowe do kombinacji obciążeń $\gamma_{G}=1,35 ; \gamma_{Q}=1,50$.

Schemat statyczny przewodu spalinowego przedstawiono na rys. 4a.

Różnica temperatur

Określenie różnicy temperatur oddziaływującej na przewód według PN-EN $13084-6[5]$

$\Delta \mathrm{T}=0,1 \mathrm{~T}_{\max }$, lecz nie mniej niż $\Delta \mathrm{T}_{\min }=15 \mathrm{~K}$;

$\Delta \mathrm{T}=0,1 \times 200=20 \mathrm{~K}>\Delta \mathrm{T}_{\min }=15 \mathrm{~K}$;

$\Delta T=\Delta T^{\prime} \frac{\pi}{2} D ; \quad \Delta T^{\prime}=4 \frac{T_{\max }}{150}$, lecz nie mniej niż $\Delta \mathrm{T}^{\prime}=4 \mathrm{~K} / \mathrm{m}$

$\Delta T^{\prime}=4 \frac{200}{150}=5,33 \mathrm{~K} / \mathrm{m}>\Delta T^{\prime}=4 \mathrm{~K} / \mathrm{m}$

$\Delta \mathrm{T}=5,33 \frac{\pi}{2} \cdot 1,62=13,6 \mathrm{~K}$

Wobec powyższych wartości przyjęto różnicę temperatur $\Delta \mathrm{T}=13,6 \mathrm{~K}$.

Schemat statyczny przewodu spalinowego pokazano na rys. 4a, przyjęto utwierdzenie przewodu $\mathrm{w}$ fundamencie komina oraz podparcie podporą ślizgową przy wierzchołku komina na poziomie $+59,0 \mathrm{~m}$. 


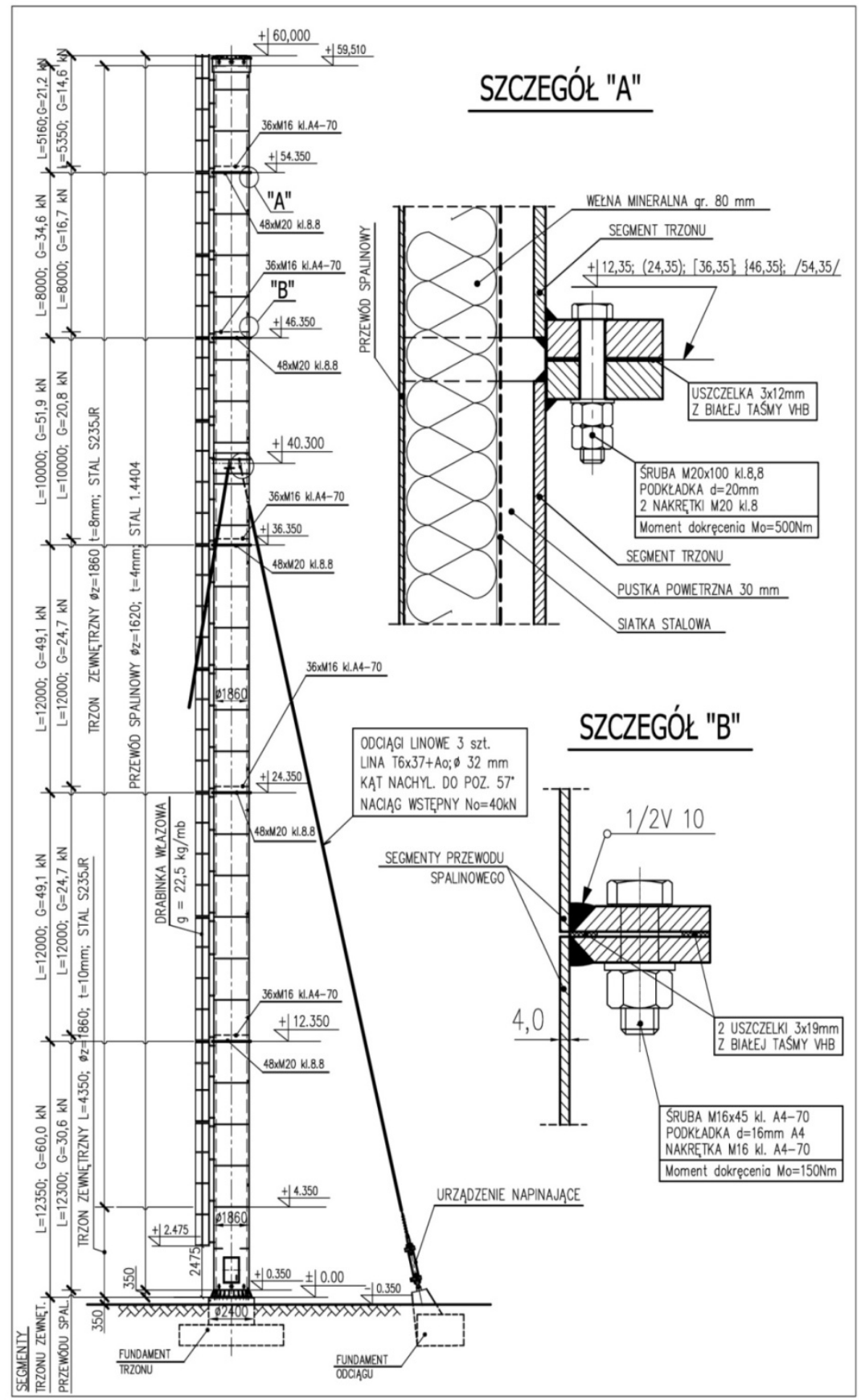

Rys. 3. Przykład obliczeniowy - rysunek konstrukcyjny komina

Fig. 3. Design example - constructional layout of the chimney 
Wartości momentów zginających od różnicy temperatur w utwierdzeniu (rys. 4b)

$M_{1}=\frac{3}{2} \cdot \frac{\alpha_{t} \cdot \Delta T \cdot E \cdot I_{1}}{d_{z}}$

$I_{1}=\frac{\pi}{64}\left(d_{z}^{4}-d_{W}^{4}\right)=\frac{\pi}{64}\left(1620^{4}-1613,5^{4}\right)=5,394 \times 10^{9} \mathrm{~mm}^{4}$

Momenty w utwierdzeniu przy grubości ścianki $\mathrm{t}_{1}=3,25 \mathrm{~mm}$ :

$M_{1}=\frac{3}{2} \cdot \frac{16,5 \cdot 10^{-6} \cdot 13,6 \cdot 1,90 \cdot 10^{5} \cdot 5,394 \cdot 10^{9}}{1620}=212,9 \cdot 10^{6} \mathrm{~N} \mathrm{~mm}$;

a)

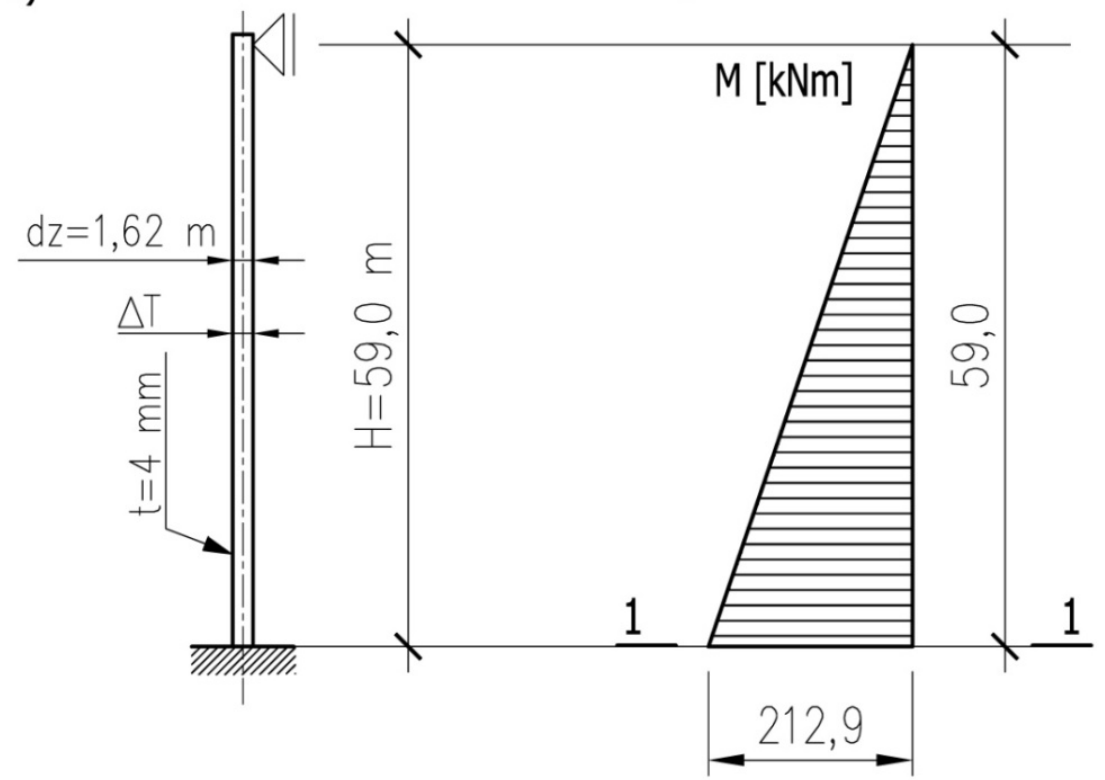

Rys. 4. Przykład obliczeniowy: a) schemat statyczny rurowego przewodu spalinowego b) moment zginający od różnicy temperatury wkładu (przewodu)

Fig. 4. Design example: a) statical tubular beam system, b) bending moment in the liner

Wartości obliczeniowe sil wewnętrznych w rozpatrywanym przekroju 1 - 1

Momenty zginające:

$M_{k, 1}=212,9 \mathrm{kNm} ; \quad M_{d_{1} 1}=M_{k, 1} \cdot \gamma_{Q}=212,9 \cdot 1,50=319,4 \mathrm{kNm}$

Sily osiowe:

Wartość sił osiowych przyjęto konserwatywnie bez odejmowania ubytków korozyjnych.

$N_{k, 1}=132,1 \mathrm{kN} ; \quad N_{d, 1}=N_{k, 1} \cdot \gamma_{G}=132,1 \cdot 1,35=178 \mathrm{kN}$

$N_{k, 1}=132,1 \mathrm{kN} ; \quad N_{d, 1, m_{m i n}}=N_{k, 1} \cdot \gamma_{G_{t} \text { min }}=132,1 \cdot 0,9=119 \mathrm{kN}$

Siły poprzeczne pominięto. 
Sprawdzenie stanu granicznego powłoki według PN-EN 1993-1-6 [2]

Obliczeniowa grubość powłoki $\mathrm{t}_{1}=3,25 \mathrm{~mm}$

Warunek stanu granicznego LS1

Naprężenia rozciągające w powłoce:

$$
\begin{aligned}
& \sigma_{x, t} \leq \frac{f_{y}}{Y_{M 0}}=\frac{137}{1,1}=124,5 \frac{N}{m^{2}} \\
& \sigma_{x, t}=\frac{N_{d, 1, m i n}}{2 \pi \cdot r_{m, 1} \cdot t_{1}}-\frac{M_{d, 1}}{\pi \cdot\left(r_{m, 2}\right)^{2} \cdot t_{1}} \\
& \sigma_{x, z}=\frac{119 \cdot 10^{3}}{2 \pi \cdot 808,4 \cdot 3,25}-\frac{319,4 \cdot 10^{6}}{\pi \cdot(808,4)^{2} \cdot 3,25}=-40,7 \frac{N}{m^{2}}<\frac{f_{y}}{\gamma_{M 0}}=124,5 \frac{N}{m^{2}}
\end{aligned}
$$

Warunek jest spełniony ze znacznym zapasem.

Sprawdzenie stateczności powłoki LS3

Naprężenia ściskające południkowe w powłoce:

$$
\begin{aligned}
& d_{1}=b_{t}=1620 \mathrm{~mm} \quad-\text { średnica zewnętrzna przewodu, } \\
& r_{1}=\frac{b_{t}}{2}=810 \mathrm{~mm} \quad-\text { promień zewnętrzny przewodu, } \\
& r_{m, 1}=\frac{b_{t}-t_{1}}{2}=\frac{1620-3,25}{2}=808,375 \mathrm{~mm} \\
& \sigma_{x_{n} e}=\frac{N_{d_{1}, 1}}{2 \pi \cdot r_{m, 1} \cdot t_{2}}+\frac{M_{d, 1}}{\pi \cdot\left(r_{m, 1}\right)^{2} \cdot t_{1}} \\
& \sigma_{x_{n} e}=\frac{178 \cdot 10^{3}}{2 \pi \cdot 808,4 \cdot 3,25}+\frac{319,4 \cdot 10^{6}}{\pi \cdot(808,4)^{2} \cdot 3,25}=58,7 \frac{\mathrm{N}}{\mathrm{mm}^{2}}
\end{aligned}
$$

Warunek stateczności:

$\frac{r_{m, 1}}{t_{1}}=\frac{808,4}{3,25}=248,7>0,03 \frac{E}{f_{y}}=0,03 \cdot \frac{190000}{137}=41,6$

należy sprawdzić stateczność powłoki.

Parametr długości powłoki:

$\mathrm{L}_{\mathrm{p}, 2}=12 \mathrm{~m}$ - długość segmentu powłoki.

$\omega=\frac{L_{p, 1}}{\sqrt{r_{m, 1}-t_{1}}}=\frac{12}{\sqrt{0,808 \cdot 0,00325}}=234,1>0,5 \frac{r_{m, 1}}{t_{1}}=0,5 \cdot \frac{0,808}{0,00325}=124,4$

jest to powłoka długa.

Południkowe naprężenia krytyczne przy wyboczeniu sprężystym

Warunki brzegowe:

Dố: $B C 1$

Góra: $B C 2 \rightarrow C_{x b}=\mathbf{3}$

$$
C_{x}=\max \left[1+\frac{0,2}{C_{x b}} \cdot\left(1-2 \omega \cdot \frac{t_{1}}{r_{m, 1}}\right) ; 0,6\right]
$$


$C_{x}=\max \left[1+\frac{0,2}{3} \cdot\left(1-2 \cdot 234,1 \cdot \frac{3,25}{808,4}\right) ; 0,6\right]=\max [0,941 ; 0,6]=0.941$

$\sigma_{x_{n} \text { Rer }}=0,605 \cdot E \cdot \frac{t_{1}}{r_{m, 1}} \cdot C_{x}$

$\sigma_{x, \text { Rer }}=0,605 \cdot 190000 \cdot \frac{3,25}{808,4} \cdot 0,941=435,7 \frac{\mathrm{N}}{\mathrm{mm}^{2}}$

Parametry wyboczenia południkowego:

- Parametr jakości wytwarzania $Q_{x}=16$

- Charakterystyczna amplituda imperfekcji

$$
\Delta_{w k}=\frac{1}{Q_{x}} \cdot \sqrt{r_{m, 1} \cdot t_{1}}
$$

$$
\mathbf{\Delta}_{w k}=\frac{1}{16} \cdot \sqrt{808,4-3,25}=3,204 \mathrm{~mm}
$$

Współczynniki redukcyjne:

$$
\beta_{x}=0,6 ; \quad \eta_{x}=1,0
$$

$\alpha_{x}=\frac{0,62}{1+1,91 \cdot\left(\frac{\Delta_{w k}}{t_{1}}\right)^{1.44}}=\frac{0,62}{1+1,91 \cdot\left(\frac{3,204}{3,25}\right)^{1,44}}=0,216$

Smukłości graniczne:

$$
\begin{aligned}
& \lambda_{\infty x}=0,20+0,10 \cdot\left(\frac{\left|\sigma_{x, t}\right|}{\left|\sigma_{x, a}\right|}\right)=0,20+0,10 \cdot\left(\frac{|-40,7|}{|58,7|}\right)=0,269 \\
& \lambda_{p x}=\sqrt{\frac{\alpha_{x}}{1-\beta_{x}}}=\sqrt{\frac{0,216}{1-0,6}}=0,735
\end{aligned}
$$

Smukłość powłoki:

$$
\lambda_{\alpha x}=0,269<\lambda_{x}=\sqrt{\frac{f_{y}}{\sigma_{x_{k} \text { ECr }}}}=\sqrt{\frac{137}{435,7}}=0,561<\lambda_{p x}=0,735
$$

Zatem:

$\chi_{x}=1-\beta_{x} \cdot\left(\frac{\lambda_{x}-\lambda_{\infty x}}{\lambda_{w x}-\lambda_{\infty x}}\right)^{\eta_{x}}=1-0,6 \cdot\left(\frac{0,561-0,269}{0,735-0,269}\right)^{1}=0,624$

Naprężenia ściskające południkowe w powłoce:

$\mathrm{d}_{1} \mathrm{~b}_{\mathrm{t}}=1620 \mathrm{~mm} \quad$ - średnica zewnętrzna przewodu, 
$\mathrm{b}_{\mathrm{w}} \quad 1613,5 \mathrm{~mm}$

- średnica wewnętrzna przewodu,

$\mathrm{r}_{1} 810 \mathrm{~mm} \quad$ - promień zewnętrzny przewodu,

$1_{\text {cr }} \quad 0,8 \times 59=47,2 \mathrm{~m}$ - długość wyboczenia dla przyjętego schematu belki (pręta) jednostronnie utwierdzonej.

$$
\begin{aligned}
& I_{o}=\frac{\pi}{64} \cdot\left(b_{t}^{4}-b_{w}^{4}\right)=\frac{\pi}{64} \cdot\left((162)^{4}-(161,35)^{4}\right)=539354 \mathrm{~cm}^{4} \\
& A=\frac{\pi}{4} \cdot\left(b_{t}^{2}-b_{W}^{2}\right)=\frac{\pi}{4} \cdot\left((162)^{2}-(161,35)^{2}\right)=165,1 \mathrm{~cm}^{2} \\
& i_{o}=\sqrt{\frac{I_{o}}{A}}=\sqrt{\frac{539354}{165,1}}=57,16 \mathrm{~cm} \\
& \lambda_{o}=\frac{l_{c r}}{i_{o}}=\frac{4720}{57,13}=82,57 \\
& \lambda_{1}=93,9 \cdot \sqrt{\frac{235 \mathrm{MPa}}{f_{y}}}=93,9 \cdot \sqrt{\frac{235}{137}}=122,98 \\
& \lambda=\lambda_{o} \cdot \frac{\sqrt{X_{x}}}{\lambda_{1}}=82,57 \cdot \frac{\sqrt{0,628}}{122,98}=0,53 \\
& \alpha=0,49 \\
& \text { nych. } \\
& \Phi=0,5\left[1+a(\lambda-0,4)+\lambda^{2}\right]=0,5\left[1+0,49 \cdot(0,53-0,4)+0,53^{2}\right]=0,67 \\
& \chi_{i}=\frac{1}{\Phi+\sqrt{\Phi^{2}-\lambda}}=\frac{1}{0,67+\sqrt{0,67^{2}-0,53}}=0,92 \\
& \sigma_{x, c X}=\frac{N_{d, 1}}{\chi_{i} \cdot 2 \pi \cdot r_{m, 1} \cdot t_{1}}+\frac{M_{d_{1} 1}}{\pi \cdot r_{m, 1}^{2} \cdot t_{1}} \\
& \sigma_{x, c X}=\frac{178 \cdot 10^{3}}{0,92 \cdot 2 \pi \cdot 808,4 \cdot 3,25}+\frac{319,4 \cdot 10^{6}}{\pi \cdot(808,4)^{2} \cdot 3,25}=59,6 \frac{N}{\mathrm{~mm}^{2}}
\end{aligned}
$$

Warunek stanu granicznego:

$$
\begin{aligned}
& \sigma_{x_{n} R k}=\chi_{x} \cdot f_{y}=0,624 \cdot 137=85,5 \frac{\mathrm{N}}{\mathrm{mm}^{2}} \\
& \sigma_{x, R d}=\frac{\sigma_{x, R k}}{Y_{M 1}}=\frac{85,5}{1,1}=77,7 \frac{\mathrm{N}}{\mathrm{mm}^{2}} \\
& \frac{\sigma_{x_{n}, C_{X}}}{\sigma_{x, R d}}=\frac{59,6}{77,7}=0,77<1,0
\end{aligned}
$$

Warunek został spełniony z 23\% zapasem. Dalsze obliczenia zbędne.

\section{Podsumowanie}

Projektowanie kominów stalowych według Eurokodów, na założony okres eksploatacji wymaga odpowiedniej wiedzy często interdyscyplinarnej i doświadczenia. Stąd konieczność współpracy konstruktora, technologa i użytkownika, w celu opracowania danych wyjściowych pozwalających okre- 
ślić stopień zagrożeń korozyjnych, a następnie właściwy dobór rozwiązań materiałowo - konstrukcyjnych, gwarantujących wymaganą trwałość kominów możliwość eksploatacji przez zalecony w normie PN-EN 1993-3-2 [3] projektowany okres użytkowania, wynoszący minimum 30 lat.

W ramach racjonalnego zużycia energii, $w$ wielu ciepłowniach i kotłowniach są montowane różnego rodzaju instalacje odzysku ciepła ze spalin, zastosowanie takich rozwiązań (w postaci ekonomizerów) skutkuje między innymi obniżeniem temperatury odprowadzanych spalin, często na granicy temperatury kwasowego punktu rosy. Przy takich parametrach spalin zawierających na ogół związki siarki, budowa kominów jednopowłokowych ze stali zwykłej nieodpornej na korozję, staje się rozwiązaniem ekonomicznie nieuzasadnionym. Przyczyną jest przede wszystkim zbyt krótki okres eksploatacji ze względu na intensywną korozję wżerową ścianki komina. Takie uwarunkowania technologiczne tzn. niska temperatura odprowadzanych spalin oraz dodatkowo wprowadzenie przez Eurokody nowych bardziej rygorystycznych (niż dotychczas) wymagań materiałowych spowodowało potrzebę poszukiwania nowych rozwiązań konstrukcyjno-materiałowych w zakresie realizacji kominów stalowych. Coraz powszechniej stosowanym rozwiązaniem będą kominy dwupowłokowe $\mathrm{z}$ wewnętrznym ocieplonym przewodem spalinowym ze stali stopowej - nierdzewnej. Rozdzielenie funkcji technologicznej i konstrukcyjnej jest korzystnym rozwiązaniem z punktu widzenia trwałości a dodatkowym atutem takich kominów jest możliwość wymiany jedynie przewodu spalinowego, w przypadku jego całkowitego skorodowania oraz możliwość ponownego wykorzystania trzonu nośnego. Przewody spalinowe w takich kominach projektuje się jedynie na naprężenia wynikające $\mathrm{z}$ oddziaływania różnicy temperatury z uwzględnieniem ubytków korozyjnych, jak to pokazano w zamieszczonym w referacie przykładzie obliczeniowym.

Budowa kominów dwupowłokowych $\mathrm{z}$ wewnętrznym przewodem spalinowym, $\mathrm{z}$ prawidłowo dobranego gatunku stali odpornej na korozję i z odpowiednio przyjętą grubością wyjściową ścianki przewodu gwarantuje wymaganą trwałość tych specjalnych budowli przemysłowych.

\section{Literatura}

[1] PN-EN 1993-1-4: 2007. Eurokod 3. Projektowanie konstrukcji stalowych. Część 1-4: Reguły uzupełniające dla konstrukcji ze stali nierdzewnych.

[2] PN-EN 1993-1-6: 2007 Eurokod 3: Projektowanie konstrukcji stalowych - Część 1-6: Wytrzymałość i stateczność konstrukcji powłokowych.

[3] PN-EN 1993-3-2: 2008. Eurokod 3. Projektowanie konstrukcji stalowych. Część 3-2: Wieże, maszty i kominy - Kominy.

[4] PN-EN 13084-1: 2007. Kominy wolno stojące. Część 1: Wymagania ogólne.

[5] PN-EN 13084-6: 2005. Kominy wolno stojące. Część 6: Wykładziny stalowe. Projektowanie i wykonanie. 
[6] PN-EN 13084-7: 2006. Kominy wolno stojące. Część 7: Wymagania dotyczące cylindrycznych wyrobów stalowych przeznaczonych na jednopowłokowe kominy stalowe oraz stalowe wykładziny.

[7] PN-EN 10088: 2007. Stale odporne na korozję.

[8] Kubiszyn W.: Wybrane aspekty projektowania, wykonawstwa i montażu dwupowłokowych kominów stalowych. Inżynieria i Budownictwo, Nr 9/2012.

[9] Rykaluk K.: Konstrukcje stalowe. Kominy. Wieże. Maszty Oficyna Wydawnicza Politechniki Wrocławskiej, Wrocław 2004.

[10] Włodarczyk W.: Problemy obliczeniowe i konstrukcyjne w projektowaniu kominów stalowych. Materiały Konferencji WPPK. Ustroń 2004.

[11] Włodarczyk W.: O niektórych problemach projektowania kominów stalowych. Inżynieria i Budownictwo, Nr 11/2004.

[12] Włodarczyk W.: Problemy trwałości w projektowaniu kominów stalowych według Eurokodu 3. Inżynieria i Budownictwo, Nr 9/2010.

[13] Włodarczyk W.: Problemy projektowania kominów stalowych z uwzględnieniem Eurokodów. Materiały Konferencji WPPK. Szczyrk 2012.

\section{CHOSEN ASPECTS OF SHAPING, DESIGNING AND EXECUTION OF STEEL LINERS IN DOUBLE WALL CHIMNEYS}

\section{S u m m a r y}

The paper presents problems of shaping, designing and execution of steel liners which are made of stainless steel in double wall chimneys. Taking an example of existing double wall chimney, problems with providing required durability in designing of steel chimneys with PN-EN 1993-3-2 and PN-EN 13084-1code condition were taken into consideration. Applied material and structural solutions were described as well as the execution rules of the steel liners. Principles of chimney liner's design were presented with regard to effects of the temperature difference according to PN-EN13084-6 code. These principles are illustrated with proper design example. In conclusion, the paper recommends the implementation of double wall steel chimneys with stainless steel liner as a solution to meet the current standard requirements for durability.

Keywords: steel chimneys, stainless steel, steel liners, durability of steel chimneys, actions of temperature difference

Przestano do redakcji:30.05.2015

Przyjęto do druku:10.01.2016

DOI: $10.7862 / \mathrm{rb} .2015 .192$ 